\title{
Monitoring non-carbonated ('still') mineral waters for aerobic colonization
}

\author{
H. Leclerc ', D.A.A. Mossel ' and C. Savage ' \\ 'Insurtur National de la Suniè et de la Recherche Medicale. Villeneure d'Ascq. France und \\ $\therefore$ Depariment of the Sitence of Food of Animal Origin. Faculis of Verierinari Aledicine. \\ Unnersuls of Lirechi, Lirechi. The tietherlands \\ (Received 29 Octuber 1984: accepted is June 1985)
}

\begin{abstract}
Fifty samples each of two leading brands of French. non-carbonated ('still) mineral waters. packed in plastic botties. were stored in the dark for one month at approximately $20^{\circ} \mathrm{C}$ to allou marked proliferation of thesr autotrophic microbial flora. Upon completion of this challenge test $1250 \mathrm{ml}$ per bottle were filtered through five membranes. which were subsequently cultured on $1 / 10$ strength nutrient agar for $48 \mathrm{~h}$ at a temperature favouring the growth of thermotrophic organisms only. i.e $42 \pm 05^{\circ} \mathrm{C}$. The numbers of colonies per one litre were below $10^{3}$ in all samples and did not exceed 200 in 56-807. depending on the brand. Identification of the isolates demonstrated strong inhibition of the piychrotrophic Gram-negative types. predominating in the association flora of stored still udters and preponderance of Gram-positive. catalase-positive. facultatively anaerobic cocci. Consequently. a Reference Value for the thermotrophic autotrophic colony couni per $1 \mathrm{ml}$ in still. commercial mineral uaters of the order $m=1$ and $M=5$ seems justified. It is emphasized that. besides examining for these trivial organisms. the usual tests for marker bacteria (Escherichic coll and Lancefield group D irepiocixici) and Pseiudimionus ueruginosa should always be carried out
\end{abstract}

Key words: Mineral water, non-carbonated: Autotrophic bacteria. Thermotrophic batteria:

Bacteriological reference values

\section{Introduction}

The microbiological monitoring of bottled. 'still'. i.e. non-carbonated mineral waters has for many years occupied professional bacteriologists (Buttiaux and Boudier. 1960). Agreement on the assessment of bacteriological wholesomeness was reached quite early. The classical tests for Escherichia coli. Lancefield group D streptococci and later also Pseudomonas aeruginosa have been adopted and various reliable techniques for the detection of marker (Mossel. 1982) and other bacteria have been elaborated and validated (Leclerc. 1976: Mossel et al., 1977; van den Broek et al.. 1979: Corstiaensen et al.. 1984).

However. the determination of the aerobic colonization of non-carbonated waters and its significance have been extensively studied and amply discussed (Buttiaux and Boudier. 1960: Delabroise and Ducluzeau. 1974: Ducluzeau et al.. 1976a: Schmidt- 
Lorenz and Jaeggi, 1983;. It has been demonstrated that still mineral waters with even minimal contents of minerals become colonized in the course of distribution and storage. with psychrotrophic bacteria of various taxa with extremely low nutritional requirements. termed autotrophic organisms (Buttiaux and Boudier. 1960). These organisms lack health significance (Ducluzeau et al.. 1976a. b) and hence their colony counts per se are not very relevant. Nonetheless. if small numbers of potentially pathogenic bacteria are initially present and survive long enough in non-carbonated water. they may multiply. feeding on the products of lysis, or on the metabolites of autotrophs and thus endanger the water ultimately. This phenomenon is known as secondary colonization or 'regrowth' (Wolters and Schwartz, 1956; Nehrkorn. 1968; von Bockelmann and von Bockelmann. 1972; Thofern et al.. 1974: Geldreich et al.. 1975; van der Kooij et al., 1982). Consequently, the examination of bottled. still waters. a few weeks after bottling for markers and some pathogens is essential (WHO. 1971).

Recently. Swiss authors have suggested that the interpretation of the degree of colonization of still mineral waters can be facilitated and rationalized by limiting colony counts to those bacteria that grow well at elevated temperatures (viz. over $37^{\circ} \mathrm{C}$ ). the so-called thermotrophic types, because they found such counts to be invariably low in waters of good sanitary quality (Schaller and Schmidt-Lorenz. 1981: Schmidt-Lorenz and Jaeggi, 1983). We have established earlier that a similar approach could be followed to assess and interpret colonization of piped water and some types of food by Gram-negative bacteria (Mossel and Zwart. 1960: Leclerc et al.. 1983: Mossel et al., 1983a). The Swiss results and our own prompted a study of the feasibility of using an enumeration of thermotrophs for the monitoring of bottled. still mineral waters. by carrying out a survey on two leading French brands.

\section{Materials and Methods}

\section{Samples}

A total of fifty samples was obtained from two leading French brands of non-carbonated mineral water. They were consistently exempt of markers of faecal contamination and of Pseudomonas aerugınosa. None of these waters originated from thermal springs. They were packed in plastic bottles.

Before examination the bottles were stored for about one month in the dark, thus mimicking a reasonable storage time under practical conditions.

\section{Methods of examination}

Before their examination, all bottles were shaken intensively in order to obtain a representative sample of the association flora. The bottles were opened immediately afterwards using rigorously aseptic precautions.

Aliquots of $1250 \mathrm{ml}$ were filtered through five membranes, i.e. $250 \mathrm{ml}$ through each membrane. They were cultured on nutrient agar. diluted 1:10 (Schmidt-Lorenz and Jaeggi, 1983) for $48 \mathrm{~h}$ at $42 \pm 0.5^{\circ} \mathrm{C}$. 
Where possible. 'appropriate' plates in the sense of Mossel and Drion (1954). i.c. those containing at least 7 colonies. were used for tentative taxonomic grouping of isolates. From every particular type of colony at least three were picked at random. When more than ten colonies of a given morphology and colour were obtained. the square root of the total number was picked without bias, i.e. relying on random numbers tables.

All colonies were first of all streaked onto nutrient agar to obtain well isolated colonies. These were subsequently examined for the key taxonomic traits: morphology by Gram stain. catalase and oxidase reactions and mode of attack on glucose (Mossel et al.. 1983b). This allows reliable taxonomic grouping of Gramnegative rods (Mossel et al.. 1983a). For the further examination of cocci the API-strip method was followed (Mossel et al.. 198.3b).

In addition. $0.1 \mathrm{ml}$ aliquots of the samples were spread onto $15 \mathrm{~cm}$ diameter plates of $1: 10$-diluted nutrient agar and incubated for $3-5$ days at $22^{\circ} \mathrm{C}$. i.e. until further incubation did not lead to an increase in numbers of colonies.

\section{Results}

The numerical results for thermotrophs obtained in the survey are summarized in Table 1. The approximate taxonomic grouping of the isolates is presented in Tables II and III.

We observed consistently that, whereas psychrotrophic colony counts varied from $10^{4}$ to $10^{4} \mathrm{ml}^{-1}$. not a single specimen produced $10^{2}$ or more colonies per $1250 \mathrm{ml}$ at $42^{\circ} \mathrm{C}$. Thus, thermotrophic colony counts per $1 \mathrm{ml}$ were well below 1 . They were even less than 200 per one litre in $56-80 \%$ of the samples. depending on the brand of still mineral water examined.

Concerning the types of bacteria and other organisms isolated it was quite striking that the classical bacterial taxa predominating the autotrophic association of stored non-carbonated waters. i.e. psychrotrophic representatives of non-fermentative. Gram-negative rods (Buttiaux and Boudier. 1960: Ducluzeau et al.. 1976a: Leclerc. 1976: Schmidt-Lorenz and Jaeggi. 1983) were suppressed by the SchmidtLorenz approach in the way the Suiss group aimed. The minimal level of these bacteria found in the samples was $10^{4} \mathrm{ml}^{-1}$. Whereas the maximum numbers of colony forming units isolated at $42^{\circ} \mathrm{C}$ never exceeded about $50 \%$ of a maximal count of about 2001 '. corresponding to a $5 \log _{1,1}$ cycle reduction.

In the thermotrophic community structure of the stored water samples. catalase positive, facultatively anaerohic cocci mostly predominated. However, this community structure varied strongly amongst samples. though much more so in brand $B$ than in A. Spring water naturally contains very low numbers of coci and Bacillus spp.. probably originating from soil (Wolters and Schwartz. 1956). Differences in colony counts of these bacteria in successive samples from the same spring may result from faulty hygiene at the source and/or reduced efficacies of aseptic precautions during bottling. 


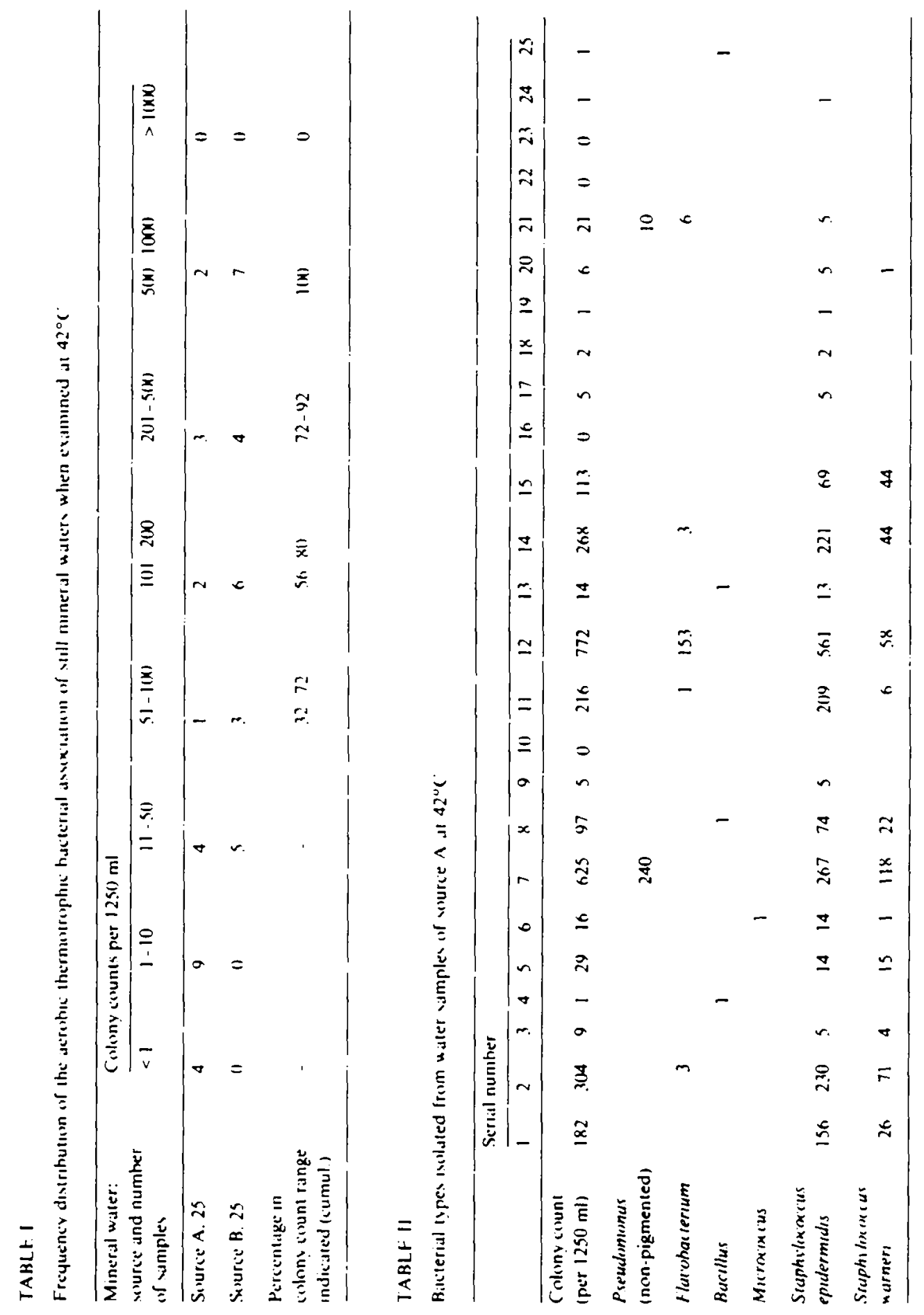




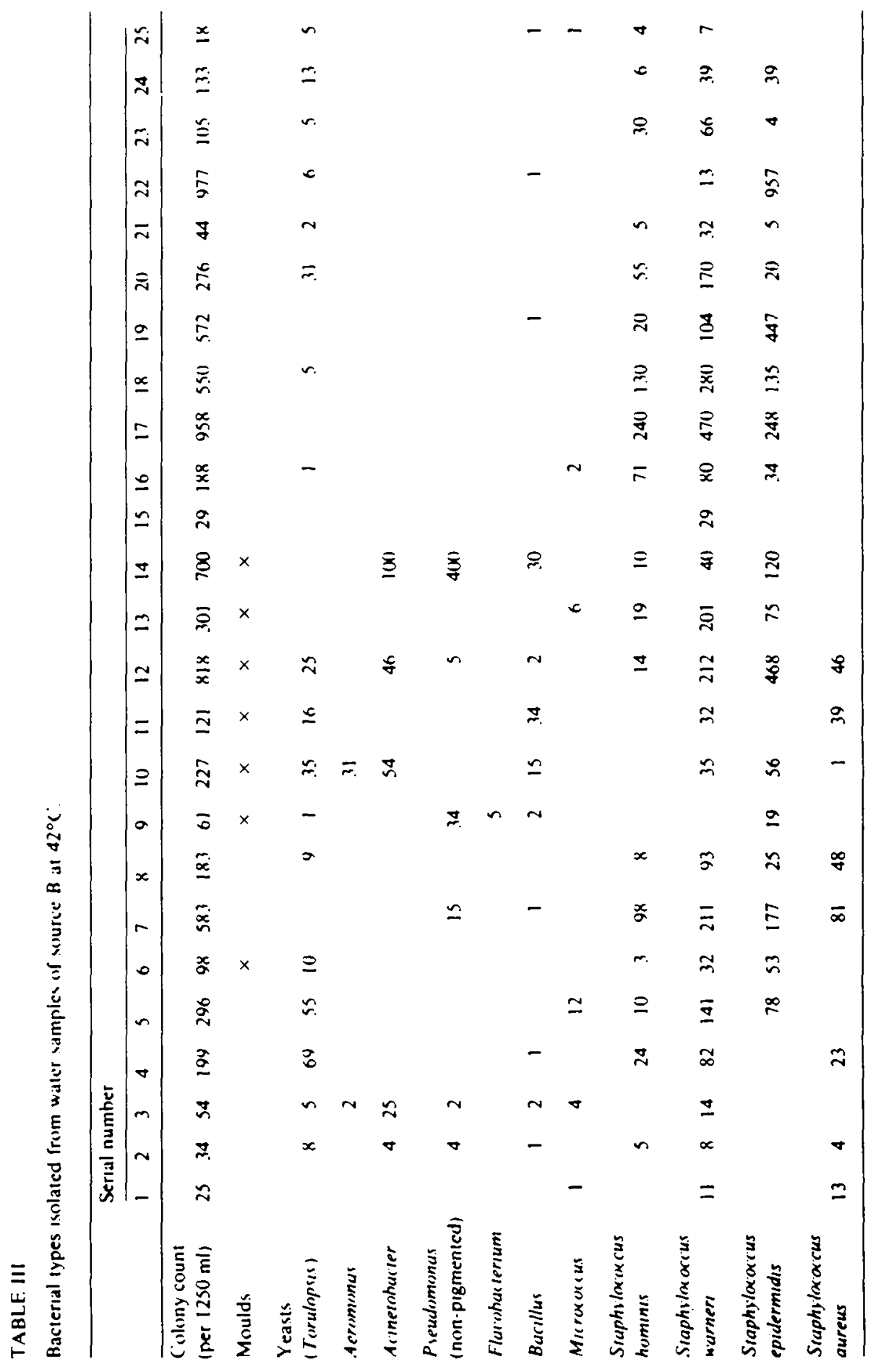




\section{Conclusion}

The results of the present study fully substantiate the observations of SchmidtLorenz et al. This may assist in resolving the long disputed problem of gauging the autotrophic association of bottled still mineral waters. Examining $1 \mathrm{ml}$ aliquots of a representative number of well-shaken samples by culturing on $1: 10$ diluted nutrient agar at $42^{\circ} \mathrm{C}$ could be all that is required.

No monitoring technique is complete. however. without a Reference Value Range against which data obtained can be gauged. Using the $m$ and $M$-model (Mossel. 1980) an $m$-value of one colony per $1 \mathrm{ml}$ of water has been demonstrated to be attainable and therefore constitutes a justified lower target value. Because. even when observing all required and practicable aseptic precautions, occasional sparse contamination of agar plates can occur and it may be wise to allow at most 5 colonies (Mossel and Drion. 1954), hence $M=5$. In cases where this number of colonies is exceeded it must be strongly recommended to assess the identity of the isolates. When these appear to be mainly Micrococcus and Bacillus species. this may point to aerial contamination during plating of the water sample under examination: Micrococcus and Bacillus predominate in the air of laboratories (Corry et al.. 1986). A repeat examination under strict aseptic conditions can establish whether the isolated colonies indeed represent the thermotrophic association flora of bottled. still mineral water, which, as in the data in Tables II and III demonstrate. can be assumed to occur at a very low level.

Finally. it should be emphasized once more that the thermotrophic colony count on a low nutrient medium as suggested by Schmidt-Lorenz et al.. and found most practicable in our investigation, should always be linked to the customarily used tests for marker organisms and Pseudomonas aeruginosu. Thermotrophic autotrophs should be counted after a suitable storage test at ambient temperatures to mimic what the fate of the initial community structure may be during storage of still mineral waters before consumption. In the course of distribution and storage. psychrotrophic autotrophs will invariably proliferate and regrowth of pathogens under these conditions is not impossible, as indicated before. Consequently an examination for markers of health risks at the end of the challenge test, when the thermotrophic autotrophs are enumerated, is mandatory.

\section{References}

Butluaux. E and A. Boudier. 1960. Comportement des bacteries autotrophes dans les eaux minerales conservées en recipients hermetiquement clos Ann. Inst. Pasteur Lılle 11. 43-53.

Corry. J.E.L.. H. Leclerc. D.A.A. Mossel. N. Skovgaard. G. Terplan and P van Nelten. 1986. A collaborative study of the quality of media prepared and poured by an automated system. Intl. J. Food Microbiol. submitted.

Corsuaensen. G.P. A.E. Eggenkamp and D.A.A. Mossel. 1984. Comparison of two methods for assessing the bacteriological condiuon of the water supply in slaughter houses. Int. J. Food Microbiol. 1, 89-98.

Delabroise. A.M and R. Ducluzeau. 1974. Le microbisme naturel de leau minerale. Son developpement. son innocuite sur l'organisme. Annal. Hyg. Med. Nutr. Langue Franc. 10. 189-192.

Ducluzeau. R.. J.M. Bochand and S. Dufresne. 1976a. La microflore autochtone de leau minerale: nature. caracieres physıologiques. significatıon hygiennique Med Nutr 12 . 115-120. 
Ducluzeau. R.. S. Dufresne and J.M. Bochand. 1976b. Inoculation of the digestive tract of axenic mice with the autochthonous bacieria of mineral water. Eur. J. Appl. Microbiol. 2. 127-134.

Geldresch. E.. D. Nash. J. Reasoner and H. Taylor. 1975. The necessity of controlling bacterial populations in potable waters - Botiled water and emergency water supplies. J Am Water Work: Assoc. 67, 117-124.

Leclerc. H., 1976. Critéres deevaluatıon des caracteristiques hygienıques el microhıologıques des eaux minérales. Annal. Ist. Super. Sanita 12, 210-217.

Leclerc. H. F. Gavini, D. Izard and P.A. Trinel. 1983. Les coliformes: mythe el realute. In: Les hacilles à Gram negatif. dinteret médical et en sante publıque: taxonomie. identification. applicatıons. Col. loques Inst. Nat. Sante Rech Med. 114.597-617.

Mossel. D.A.A. and E.F. Drion. 1954. Bacteriological requirements for and testing of sterilized milk and sterilized milk products. Netherl. Milk Dairy J. 8. 106-114

Mossel. D.A.A. and H. Zwart. 1960. The rapid tentative recognition of psychrotrophic tvpes among Enterobacteriaceac isolated from foods. J. Appl. Bacteriol. 23. 185-188

Mossel. D.A.A.. A.J.W.M. van Ekeren and I. Felderink. 1977. A sımplified procedure for the examınation of drinking water for hacieria of public health significance: the differential hydrobacteringramme. Zentralbl. Bakteriol. Parasitenkd.. Abt. I. Orıg.. B 165. 498-516

Mossel. D.A.A. 1980. Assessment and control of microbiological health risks presented hy fonds. In Foud and Health. edited by G.G. Bırch and K.J. Parker. Applied Science Publishers. London. pp. $129-166$

Mosxel. D.A.A.. 1982. Marker (ındex and indicator) organisms in food and drinking water. Semantics. ecology. taxonomy and enumeration. Antonie van Leeuwenhoek 48. 609-611

Mossel. D.A.A.. P. van Netten and H. van der Zee. 1983a. Ecological-taxonomic studies on Gram-negative rod shaped bacteria, predominating in the communttv structure of fresh meats and poultry and in such commodities processed for safety. In: Les bacilles a Gram negutif dinteret medical el en sante publique Taxonomie. Identification. applications. Colloques Inst Vat. Sante Rech. Med. 114. $629-663$

Mossel. D.A.A.. N Richard. J.P. Gayral and C. Brissuel, 1983h Etude comparative des tests preliminaires pour lidentification des hacteries isolees des matieres alımentaires. des eaux et d'autres produits biologiques Sci. Aliments 3.91-115

Nehrkorn. A.. 1968. Grundwasserkeımzahlen bel Anuendung nahrsioffarmer Substrate Genundheits-Ing 89. 88

Schaller. $P$ and W. Schmidt-Lorenz. 1980. Flore microbienne de quatri eaux minérales non gazéfices et mises en houteilles. I Dénombremeni de colonies. composition grossiere de la flore et caracteres du groupe de bacieries Gram negalif pigmenices en jaune. Zhl. Bakieriol Hyg.. I. Ahi. Orig C 1. $3.30-347$

Schaller. P and W. Schmidt.Lorenz, 1981. Flore murobienne de quatre eaux minerales non gazeifiees et mises en houtelles. Il. Les Pseudimonas el autres bacteries a Gram negauf. Composilion fine de la note. Zhl Bakteriol. Hyg.. I. Abt. Orıg. C 2. 179-196.

Schmidt-Lorenz. W. and N. Jaeggi. 1983. Colony counts at $42^{\circ} \mathrm{C}$ for the evaluation of the hygienic quality of bottled natural uncarbonated mineral water Microbiol.. Aliments. Nutrition 1. 377-391

Thofern. E.. K. Botzenhart and K. Speh. 1974 Untersuchungen zur Verkeımung von Trınkwasser GasWasserf 115. 459-460. 538-541

Van den Brnek. M.J.M. D.A.A. Mosiel. A.E. Egzenkamp. I Eelderink and M.E. Verouden. 1979. The microbial association of hivalve shellfish intended for consumplion in the ran state. with particular reference to safety. Arch. Lebensm. Hyg 30. $98-103$.

Van der K(x)j]. D. J.P. Oranje and W.A.M. Hijnen. 1982. Growih of Preudionionai aeruginosa in lap water in relation to utilization of substrates at concentrations of a feu micrograms per liter. Appl. Environm. Microbiol. 44. 1086-1095.

von Boxkelmann. I. and B. von Bockelmann. 1972. Bakteriologische (Intersuchungen an verpacktem und gelageriem stillen Trinkwasser. Verpack Rundschau 23. $1036-1039$

Wolters. N. and W. Schwartz. 1956. Untersuchungen uber Vorkommen und Verhalten von Mikruorganis. men in reinen Grundwassern. Arch. Hydrohiol. 51. 500-541

World Health Organization. International standards for drinking water 3rd edn.. (ieneve. 1971. 